\title{
Morphophysiological and phytochemical changes of Mentha piperita using calcium, potassium, iron and manganese nano-fertilizers
}

\author{
H. Bagheri ${ }^{1}$, A. Ladan Moghadam², E. Danaee ${ }^{2}$ and V. Abdossi ${ }^{3}$ \\ ${ }^{1}$ Department of Horticultural Sciences, Aliabad Katoul Branch, Islamic Azad University, Gorgan, Iran \\ 2 Department of Horticulture, Garmsar Branch, Islamic Azad University, Garmsar, Iran \\ ${ }^{3}$ Department of Horticultural Sciences, Science and Research Branch, Islamic Azad University, Tehran, Iran
}

\section{Summary}

This study was conducted to investigate the effects of foliar application of iron, potassium, calcium and manganese nano-chelates on morphological, physiological and biochemical traits of Mentha piperita (Peppermint) in a completely randomized design with two experiments. In the first experiment, foliar application of plants was performed with three levels of iron, potassium, calcium and manganese nano-chelates $\left(2,4\right.$ and $\left.6 \mathrm{mg} \mathrm{L}^{-1}\right)$. In the second experiment, foliar application of plants was performed with the best level of each treatment of the first experiment $\left(6 \mathrm{mg} \mathrm{L}^{-1}\right.$ in most traits for the applied elements). The second experiment also consisted of $\mathbf{1 2}$ treatments, with 3 replicates. Foliar application was performed three times during a week and after two weeks of sampling, and the traits, including fresh and dry weight of the aerial parts, total leaf chlorophyll content, protein content, peroxidase activity, total phenol content, iron, potassium, calcium and manganese content values and essential oil percentage, were evaluated. The results showed that in the first experiment, the effect of treatment on leaf protein, phenol and iron content was significant at $\mathbf{5 \%}$ and on other traits at $1 \%$. In the second experiment, the effect of treatment on leaf protein, iron and calcium content was significant at $5 \%$ and on the other traits was significant at $1 \%$. According to the results of both experiments, the effect of treatments on leaf protein and iron content values at different treatment concentrations was significant at $5 \%$ level. Among all applied concentrations Nano $\mathrm{Ch} \mathrm{Fe}_{6}$ showed the highest content in leaf fresh/dry weight, chlorophyll, peroxidase activity in the first experiment. Leaf fresh/dry weight, total leaf chlorophyll, leaf protein, peroxidase activity, phenol content, leaf iron, potassium, calcium, manganese content and essential oil percentage Nano $\mathrm{Ch}\left(\mathrm{Fe}_{6}+\mathrm{K}_{6}+\mathrm{Ca}_{6}+\mathrm{Mn}_{6}\right)$ had the highest amount in the second experiment.

Keywords

Nano ChK, Nano ChCa, Nano ChFe, Nano ChMg, peppermint, essential oil

\section{Introduction}

Mentha piperita is widely used in the pharmaceutical, food and health industries. According to studies, the main

\section{Significance of this study}

What is already known about this subject?

- The morphophysiological and phytochemical description of plant organs used nano-fertilizers and calcium, potassium, iron and manganese elements.

What are the new findings?

- Growth rate and phytochemical traits of the Mentha piperita are more possible using nano fertilizer.

What is the expected impact on horticulture?

- Nano-chelates precisely control the release of nutrients and can be an effective step towards achieving sustainable and environment-compatible horticulture.

active ingredient of Mentha piperita is menthol (30-55\%). Other compounds include methyl acetate $(17.4 \%)$ and methionone (12.7\%), polygon, menthofuran, limonene and limon (Scavroni et al., 2005). The application of low- and high-consumption and nutrient elements such as iron, potassium, calcium, and manganese as nano-chelates precisely controls the release of nutrients and can be an effective step towards achieving sustainable and environment-compatible agriculture (Cui et al., 2006). The effects of the application of manganese, copper, iron and zinc at the concentrations of $400 \mathrm{mg} \mathrm{L}^{-1}$ on morphological and physiological traits of Dracocephalum were studied. Carophyll, phenol, flavonoid content values, shoot fresh and dry weight, number of flowers per plant, essential oil percentage and components were evaluated. The results showed that manganese + copper + iron + zinc content increased to $73.64 \%$. The highest content of carophyll, phenol, flavonoid, fresh/dry weight of shoots and number of flowers per plant were also obtained in $\mathrm{Mn}$ $+\mathrm{Cu}+\mathrm{Fe}+\mathrm{Zn}$ treatment (Yadegari, 2017). The effect of the application of nitrogen and potassium at the concentration of $150 \mathrm{~kg} \mathrm{ha}^{-1}$ and phosphorus at the concentration of 250 $\mathrm{kg} \mathrm{ha}^{-1}$ on growth and yield of Thymus serpyllum was evaluated. Measurement of fresh and dry weight, leaf chlorophyll content, yield, percentage and content value of essential oil showed that nitrogen + potassium + phosphorus treatment had significant effect on the evaluated traits (Janaki et al., 2016). Foliar application is usually an emergency procedure and is recommended when an unexpected shortage occurs. It can also be the best way to do research on the effect of foliar application on the plant (Ahmadi and Jabbari, 2009). The 
use of nano-fertilizers leads to increased nutrient utilization efficiency, reduced soil toxicity, minimizing the negative effects of excessive fertilizer use and reduced the number of fertilizer application times (Shaviv, 2005). According to studies, the main active ingredient of Mentha piperita was menthol (30-55\%) and other compounds, including methylacetate $(17.4 \%)$, polygon, menthofuran, limonene, and lemon, the amount of which and other essential oil components are affected by environmental and nutritional factors (Rita and Animesh, 2011). Foliar application of low-consumption and high-consumption elements such as iron, potassium, calcium, and manganese in the form of nano-chelates due to their maintainability and precise controllability of the release of these elements, smaller particle size and easier absorption, lack of interactions in nutrient absorption, accessibility to traceability sustainable and environment-compatible agriculture can play an effective role in reducing nutrient intake and improving their effectiveness. Therefore, the aim of this study was foliar application of iron, potassium, calcium and manganese nano-chelates to improve morphological, physiological and biochemical traits of Mentha piperita.

\section{Materials and methods}

\section{Plant material and testing site}

The present study was conducted in 2018 in a commercial greenhouse in Eslamshahr with an average temperature of about 22 to $23^{\circ} \mathrm{C}$, relative humidity of about 50 to $60 \%$ and light intensity of about 60 to $70 \mu \mathrm{mol} \mathrm{m}{ }^{-2}$. Mentha piperita transplants were purchased from Tehran University Jihad Research Institute. Iron, potassium, calcium and manganese nano-chelates were also purchased from Khazra Company.

\section{Experiment conditions and treatments}

The research was designed and implemented in a completely randomized design with two experiments. In the first experiment, foliar application of plants was performed with three levels of iron, potassium, calcium and manganese nano-chelates $(2,4$, and $6 \mathrm{ppb})$. This experiment consisted of 13 treatments, each with 3 replicates, each replicate containing 3 plants and a total of 117 pots. In the second experiment, foliar application of plants was performed with the best level in each of the first treatments. The second experiment also consisted of 12 treatments, each with 3 replicates, each replicate containing 3 plants and a total of 108 pots. In this study, 4 to 6-leaf Mentha piperita plants were cultured in the appropriate media at the proportion of $(1: 1: 1)$. Foliar application was performed three times during one week and sampled after two weeks.

\section{Evaluated traits}

1. Fresh and dry weight of aerial parts. Measurements were performed with a digital scale and an oven with a precision of 0.01 .

2. Total leaf chlorophyll content. It was determined by a spectrophotometer and extracting the fresh leaves from the plant (Arnon, 1949).

3. Leaf protein. It was determined by a spectrophotometer and extracting the fresh leaves (Bradford, 1976).

4. Peroxidase activity. Measurements were made by using a spectrophotometer after the extraction of fresh leaves (Ezhilmathi, 2007).

5. Total phenolic content of leaves. It was determined after extraction of the plant extracts from the leaves using a spectrophotometer (Malik et al., 1980).
6. Iron, potassium, calcium and manganese content of leaves. The purified plant tissues were placed in an oven at $85^{\circ} \mathrm{C}$ for $4 \mathrm{~h}$. After complete drying, the sample was placed in a PTFE container for standard storage. These samples were powdered and homogenized and mixed. $2.5 \mathrm{~g}$ of this powder was added in $0.5 \mathrm{~mL}$ of $65 \%$ nitric acid, $4 \mathrm{~mL}$ of $37 \%$ hydrochloric acid, and $1.5 \mathrm{~mL}$ of folic acid at the concentration of $48 \%$, and placed in the oven until digestion. This solution was passed through Whitman paper No. 541 and filtered. Evaporation was then allowed and the residue was re-added with $1 \mathrm{~mL}$ of $25 \%$ hydrochloric acid and nitric acid. Atomic absorption apparatus (Analyst 700, Perkin Elmer, U.S.A.) was used to determine the surface area of the element, in which the iron element concentration (and other elements) was determined according to the excitation radiation intensity of the iron element (and other elements) (Florence et al., 2002). Leaf calcium and potassium were measured after preparation of samples by the method proposed by Mengel and Kirkby (1973).

7. Essential oil percentage. For extraction of essential oil from plant aerial organs Clevenger apparatus-MS (Shimadzu, model QP5050A) was used. So that $100 \mathrm{~g}$ of dry limbs were accurately weighed and then crushed by a mill, the sample was poured into the balloon of the Clevenger apparatus and $500 \mathrm{~mL}$ of distilled water was added and the essential oil was expressed as percentage (Mehrafarin et al., 2017).

\section{Data analysis}

The data were collected and entered into Excel software and analyzed by SPSS statistical software. Mean data comparison was used using Duncan's multiple range test at 1\% and $5 \%$ levels. Excel software was used to plot the graph.

\section{Results}

\section{Leaf fresh weight}

According to Figure 1, the effects of treatments in Mentha piperita, with increasing iron nano-chelate concentration from 2 to $4 \mathrm{mg} \mathrm{L}^{-1}$, more increase in leaf fresh weight than 4 to $6 \mathrm{mg} \mathrm{L}^{-1}$ was obtained. Leaf fresh weight also decreased from 4, 6 and $2 \mathrm{mg} \mathrm{L}^{-1}$ as Nano K-chelate, respectively. On the other hand, with increasing calcium nano-chelates concentration from 4 to $6 \mathrm{mg} \mathrm{L}^{-1}$, enhanced leaf fresh weight was observed more than 2 to $4 \mathrm{mg} \mathrm{L}^{-1}$. Leaf fresh weight increased proportionally among the applied concentrations of Mn. $6 \mathrm{mg} \mathrm{L}^{-1} \mathrm{Nano}$ Fe-chelate treatment with $21.32 \mathrm{~g}$ had the highest, and control treatment with $15.43 \mathrm{~g}$ had the lowest leaf fresh weight.

As shown in the analysis of variance Table 2 of the second experiment, in Mentha piperita the effect of concentrations treatment on leaf fresh weight was significant at $1 \%$ level. In bilateral treatments of applied elements, $6 \mathrm{mg} \mathrm{L}^{-1}$ Nano Fe-chelate $+6 \mathrm{mg} \mathrm{L}^{-1}$ Nano Mn-chelate treatment and in the trilateral treatments, $6 \mathrm{mg} \mathrm{L}^{-1} \mathrm{Nano}$ Fe-chelate + $6 \mathrm{mg} \mathrm{L}^{-1}$ Nano Mn-chelate $+6 \mathrm{mg} \mathrm{L}^{-1}$ Nano K-chelate treatment had the highest leaf fresh weight. Figure 2 also shows that $6 \mathrm{mg} \mathrm{L}^{-1}$ Nano Fe-chelate $+6 \mathrm{mg} \mathrm{L}^{-1} \mathrm{Nano} \mathrm{Mn}$-chelate + $6 \mathrm{mg} \mathrm{L}^{-1}$ Nano K-chelate $+6 \mathrm{mg} \mathrm{L}^{-1} \mathrm{Nano}$ Ca-chelate treatment had the highest leaf weight at $25.61 \mathrm{~g}$ and control treatment with $15.71 \mathrm{~g}$ had the lowest leaf fresh weight.

\section{Leaf dry weight}

According to the Figure 3, it was found that increased concentration of iron, calcium and manganese nano-chelates from 2 to $4 \mathrm{mg} \mathrm{L}^{-1}$ led to a greater increase in leaf dry weight 

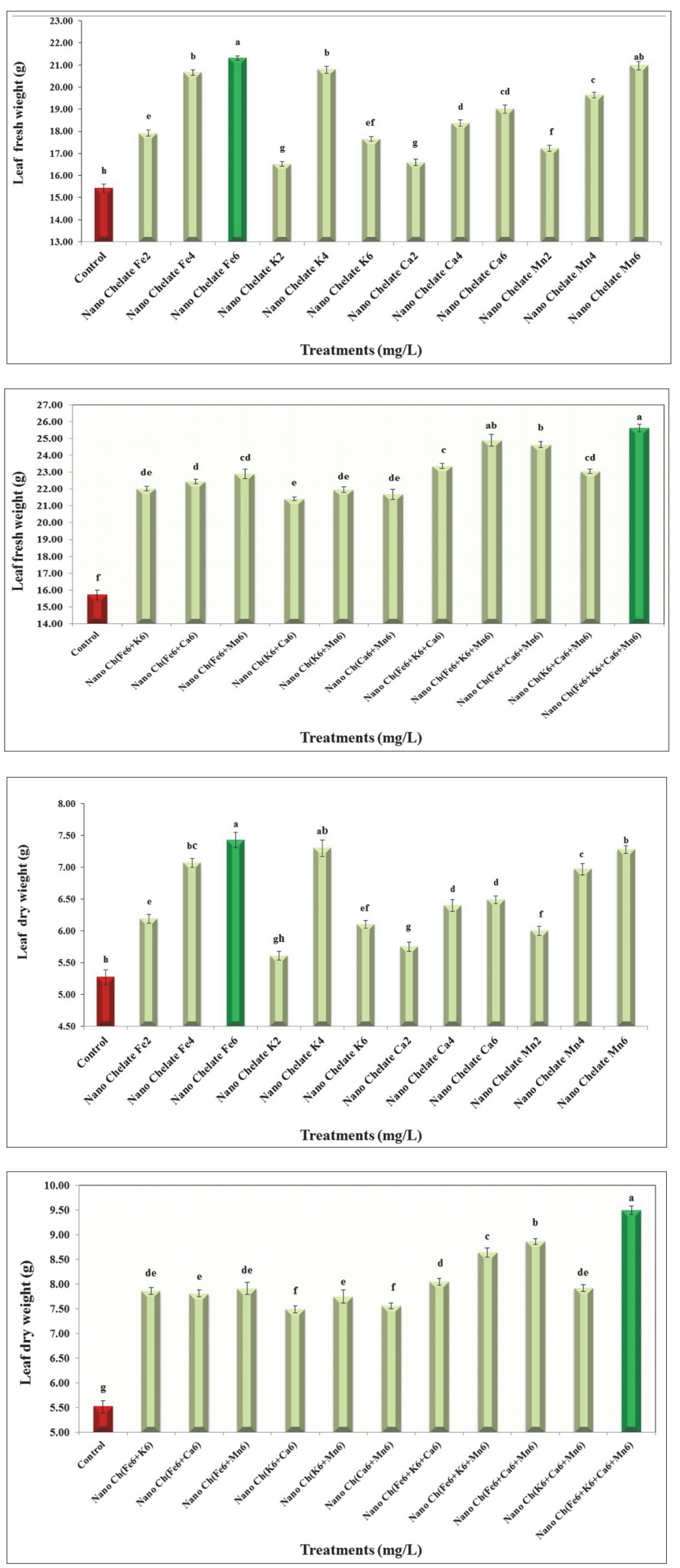

FIGURE 1. Effect of different treatments on leaf fresh weight in the first experiment. Vertical bars indicate standard error. Means followed by the same letter are not different according to Duncan's test.

FIGURE 2. Effect of different treatments on leaf fresh weight in the second experiment. Vertical bars indicate standard error. Means followed by the same letter are not different according to Duncan's test.

FIGURE 3. Effect of different treatments on leaf dry weight in the first experiment. Vertical bars indicate standard error. Means followed by the same letter are not different according to Duncan's test.

FIGURE 4. Effect of different treatments on leaf dry weight in the second experiment. Vertical bars indicate standard error. Means followed by the same letter are not different according to Duncan's test. 
TABLE 1. Results of analysis of variance of the first experiment.

\begin{tabular}{lcccccc}
\hline \multirow{2}{*}{ Variation source } & \multicolumn{7}{c}{ Mean squared } \\
\cline { 2 - 7 } & $\begin{array}{c}\text { Degree of } \\
\text { freedom }\end{array}$ & Iron & Potassium & Calcium & Manganese & $\begin{array}{c}\text { Essence } \\
\text { percentage }\end{array}$ \\
\hline Treatment & 12 & $121.203^{*}$ & $1148.698^{* *}$ & $1571.8001^{* *}$ & $180.064^{* *}$ & $0.295^{* *}$ \\
Experimental error & - & 0.293 & 0.593 & 0.639 & 0.393 & 0.005 \\
Cv $(\%)$ & - & 11.12 & 9.69 & 10.81 & 11.24 & 12.71 \\
\hline
\end{tabular}

TABLE 1. Continued. Analysis of variance of the first experiment.

\begin{tabular}{lccccccc}
\hline \multirow{2}{*}{ Variation source } & \multicolumn{7}{c}{ Mean squared } \\
\cline { 2 - 8 } & $\begin{array}{c}\text { Degree of } \\
\text { freedom }\end{array}$ & $\begin{array}{c}\text { Leaf fresh } \\
\text { weight }\end{array}$ & $\begin{array}{c}\text { Leaf dry } \\
\text { weight }\end{array}$ & $\begin{array}{c}\text { Total leaf } \\
\text { chlorophyll content }\end{array}$ & Protein & Peroxidase & Phenol \\
\hline Treatment & 12 & $33.801^{* *}$ & $4.489^{* *}$ & $6.823^{* *}$ & $36.889^{*}$ & $15.178^{* *}$ & $12.737^{* *}$ \\
Experimental error & - & 0.106 & 0.028 & 0.066 & 0.273 & 0.063 & 0.051 \\
Cv $(\%)$ & - & 9.47 & 11.77 & 12.36 & 11.65 & 11.32 & 12.62 \\
\hline$*$
\end{tabular}

**, ${ }^{*}$, ns, respectively, significant at $1 \%$ and $5 \%$ probability levels, and nonsignificant.

TABLE 2. Results of analysis of variance analysis of the second experiment.

\begin{tabular}{lccccccc}
\hline \multirow{2}{*}{ Variation source } & \multicolumn{7}{c}{ Mean squared } \\
\cline { 2 - 7 } & $\begin{array}{c}\text { Degree of } \\
\text { freedom }\end{array}$ & $\begin{array}{c}\text { Leaf fresh } \\
\text { weight }\end{array}$ & $\begin{array}{c}\text { Leaf dry } \\
\text { weight }\end{array}$ & $\begin{array}{c}\text { Total leaf } \\
\text { chlorophyll content }\end{array}$ & Protein & Peroxidase & Phenol \\
\hline Treatment & 11 & $56.980^{* *}$ & $8.165^{* *}$ & $15.560^{* *}$ & $103.023^{*}$ & $34.137^{* *}$ & $25.455^{\star *}$ \\
Experimental error & - & 0.091 & 0.037 & 0.067 & 0.289 & 0.080 & 0.052 \\
Cv $(\%)$ & - & 11.51 & 12.35 & 10.79 & 11.69 & 12.31 & 11.45 \\
\hline
\end{tabular}

TABLE 2. Continued. Results of analysis of variance of the second experiment.

\begin{tabular}{lcccccc}
\hline \multirow{2}{*}{ Variation source } & \multicolumn{7}{c}{ Mean squared } \\
\cline { 2 - 7 } & $\begin{array}{c}\text { Degree of } \\
\text { freedom }\end{array}$ & Iron & Potassium & Calcium & Manganese & $\begin{array}{c}\text { Essence } \\
\text { percentage }\end{array}$ \\
\hline Treatment & 11 & $145.439^{*}$ & $1854.496^{* *}$ & $1771.496^{*}$ & $389.489^{* *}$ & $0.183^{* *}$ \\
Experimental error & - & 0.389 & 0.682 & 0.779 & 0.375 & 0.004 \\
Variation (\%) & - & 12.50 & 12.03 & 10.11 & 11.18 & 9.34 \\
\hline
\end{tabular}

**, ${ }^{*}$, ns, respectively, significant at $1 \%$ and $5 \%$ probability levels, and nonsignificant.

than 4 to $6 \mathrm{mg} \mathrm{L}^{-1}$. Among different concentrations of potassium nano-chelate, leaf fresh weight also decreased in order of $4 \mathrm{mg} \mathrm{L}^{-1}$ Nano K-chelate to $6 \mathrm{mg} \mathrm{L}^{-1}$ Nano K-chelate and $2 \mathrm{mg} \mathrm{L}^{-1}$ Nano K-chelate, respectively. $6 \mathrm{mg} \mathrm{L}^{-1} \mathrm{Nano}$ Fe-chelate treatment with $7.43 \mathrm{~g}$ had the highest, and control treatment with $5.27 \mathrm{~g}$ had the lowest leaf dry weight.

As shown in Table 2 for leaf dry weight of Mentha piperita in different treatments, it is observed that the effect of treatment on leaf dry weight at different treatment concentrations was significant at $1 \%$ level. In bilateral treatments, $6 \mathrm{mg} \mathrm{L}^{-1}$ Nano Fe-chelate $+6 \mathrm{mg} \mathrm{L}^{-1}$ Nano Mn-chelate treatment and in trilateral treatments, $6 \mathrm{mg} \mathrm{L}^{-1} \mathrm{Nano}$ Fe-chelate $+6 \mathrm{mg} \mathrm{L}^{-1}$ Nano Mn-chelate $+6 \mathrm{mg} \mathrm{L}^{-1}$ Nano Ca-chelate treatment had the highest leaf dry weight. In addition, Figure 4 shows that $6 \mathrm{mg} \mathrm{L}^{-1} \mathrm{Nano}$ Fe-chelate $+6 \mathrm{mg} \mathrm{L}^{-1} \mathrm{Nano}$ K-chelate $+6 \mathrm{mg} \mathrm{L}^{-1}$ Nano Ca-chelate $+6 \mathrm{mg} \mathrm{L}^{-1}$ Nano Mn-chelate treatment had the highest leaf dry weight and control treatment with $5.52 \mathrm{~g}$ had the lowest, respectively.

\section{Total leaf chlorophyll content}

According to the Figure 5, the total leaf chlorophyll content was increased proportionally with different treatment in Mentha piperita. Among the applied concentrations of iron, potassium, calcium and manganese nano-chelate. 6 $\mathrm{mg} \mathrm{L}^{-1}$ Nano Fe-chelate treatment with $14.9383 \mathrm{mg} \mathrm{g}^{-1}$ F.W. had the highest and control treatment with $11.889 \mathrm{mg} \mathrm{g}^{-1}$ fresh weight had the lowest total leaf chlorophyll content.
As shown in Table 2, associated with the total leaf chlorophyll content in Mentha piperita in different treatments, the effect of treatment on total leaf chlorophyll content at different treatments concentrations was significant at $1 \%$ level. In bilateral treatments, $6 \mathrm{mg} \mathrm{L}^{-1} \mathrm{Nano}$ Fe-chelate +6 $\mathrm{mg} \mathrm{L}^{-1}$ Nano Mn-chelate and in trilateral treatments, $6 \mathrm{mg} \mathrm{L}^{-1}$ Nano Fe-chelate $+6 \mathrm{mg} \mathrm{L}^{-1}$ Nano K-chelate $+6 \mathrm{mg} \mathrm{L}^{-1}$ Nano Mn-chelate had the highest total leaf chlorophyll content. 6 $m g L^{-1}$ Nano Fe-chelate $+6 \mathrm{mg} \mathrm{L}^{-1}$ Nano K-chelate $+6 \mathrm{mg} \mathrm{L}^{-1}$ Nano Ca-chelate $+6 \mathrm{mg} \mathrm{L}^{-1}$ Nano Mn-chelate treatment at $17.199 \mathrm{mg} \mathrm{g}^{-1}$ F.W. had the highest and control treatment with $12.0215 \mathrm{mg} \mathrm{g}^{-1} \mathrm{~F} . \mathrm{W}$. had the lowest total leaf chlorophyll content (Figure 6).

\section{Leaf protein content}

As shown in Figure 7, the effects of treatments on protein content in Mentha piperita, Nano K-chelate and Nano Fe-chelate from 2 to $4 \mathrm{mg} \mathrm{L}^{-1}$ resulted in a higher increase in protein content than increasing the concentration from 4 to $6 \mathrm{mg} \mathrm{L}^{-1}$. Increasing the concentration of calcium and manganese nano-chelates from 2 to $4 \mathrm{mg} \mathrm{L}^{-1}$, results in a significant increase in protein content which is more than increasing concentration from 4 to $6 \mathrm{mg} \mathrm{L}^{-1}$. $6 \mathrm{mg} \mathrm{L}^{-1} \mathrm{Nano} \mathrm{K}$-chelate treatment with $65.82 \mu \mathrm{g} \mathrm{mg}^{-1}$ F.W. had the highest and control treatment with $58.49 \mu \mathrm{g} \mathrm{mg}^{-1} \mathrm{~F} . \mathrm{W}$. had the lowest protein content.

According to Table 2 of the second experiment on the protein content in Mentha piperita in different treatments, 

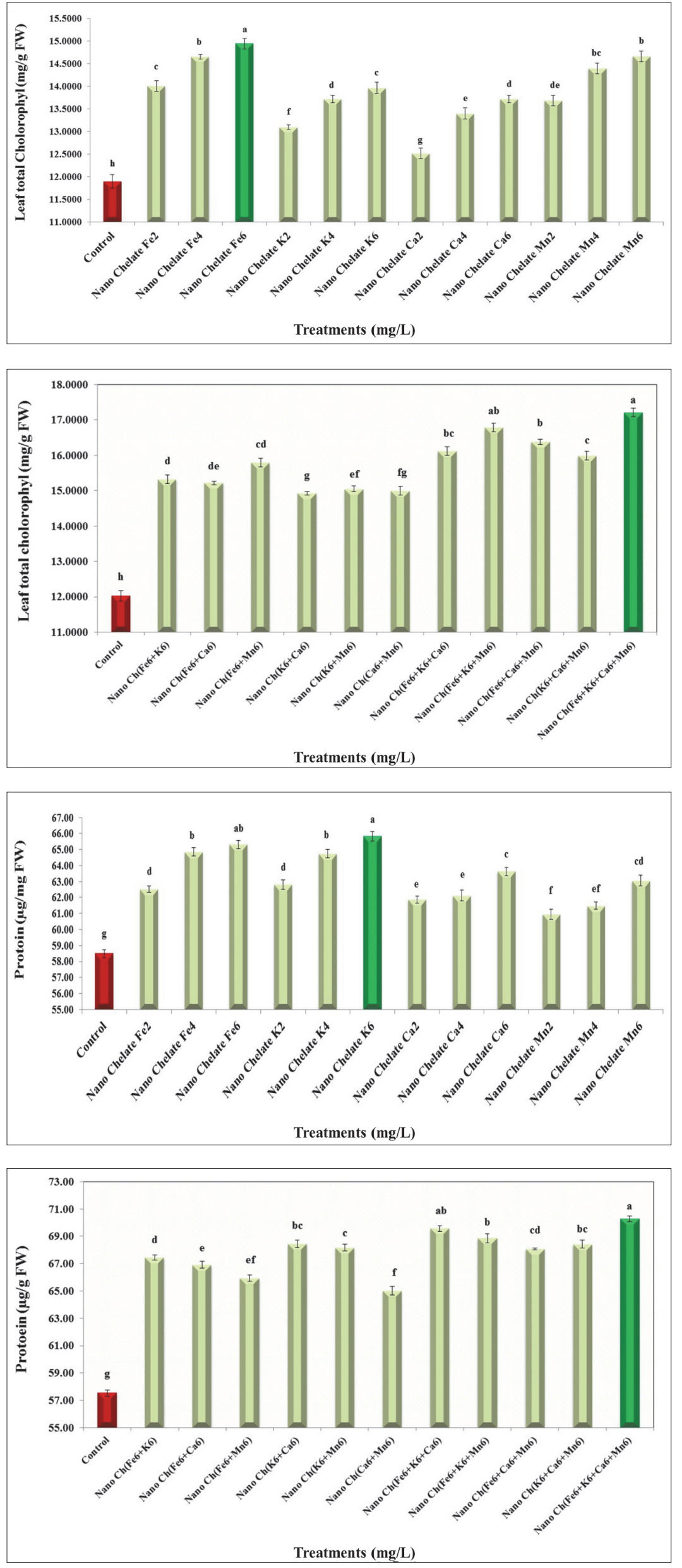

FIGURE 5. Effect of different treatments on chlorophyll content of whole leaves in the first experiment. Vertical bars indicate standard error. Means followed by the same letter are not different according to Duncan's test.

FigURE 6. Effect of different treatments on total leaf chlorophyll content in the second experiment. Vertical bars indicate standard error. Means followed by the same letter are not different according to Duncan's test.

FIGURE 7. Effect of different treatments on leaf protein content in the first experiment. Vertical bars indicate standard error. Means followed by the same letter are not different according to Duncan's test.

FIGURE 8. Effect of different treatments on leaf protein content in the second experiment. Vertical bars indicate standard error. Means followed by the same letter are not different according to Duncan's test. 

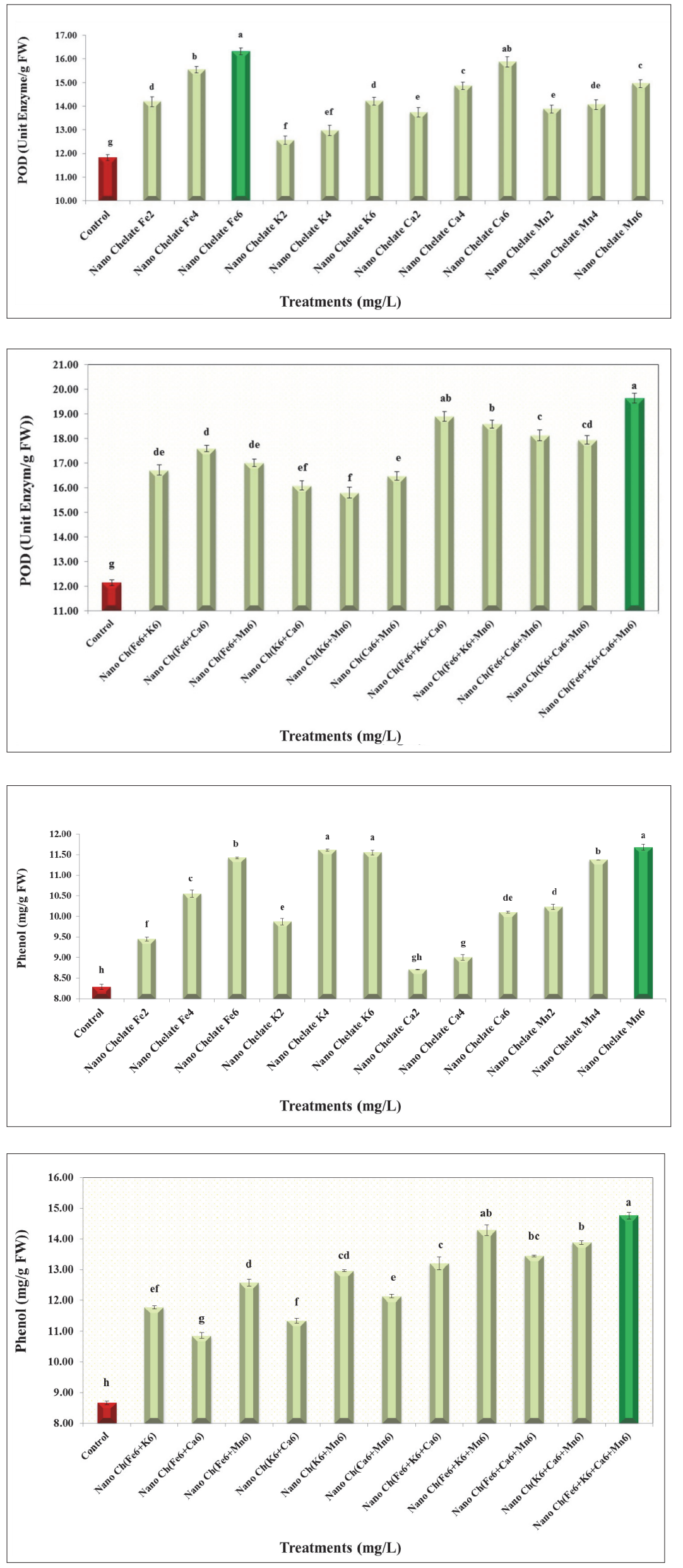

FIGURE 9. Effect of different treatments on peroxidase activity in the first experiment. Vertical bars indicate standard error. Means followed by the same letter are not different according to Duncan's test.

FIGURE 10. Effect of different treatments on peroxidase activity in the second experiment. Vertical bars indicate standard error. Means followed by the same letter are not different according to Duncan's test.

FIGURE 11. Effect of different treatments on total leaf phenol content in the first experiment. Vertical bars indicate standard error. Means followed by the same letter are not different according to Duncan's test.

FIGURE 12. Effect of different treatments on total leaf phenol content in the second experiment. Vertical bars indicate standard error. Means followed by the same letter are not different according to Duncan's test. 

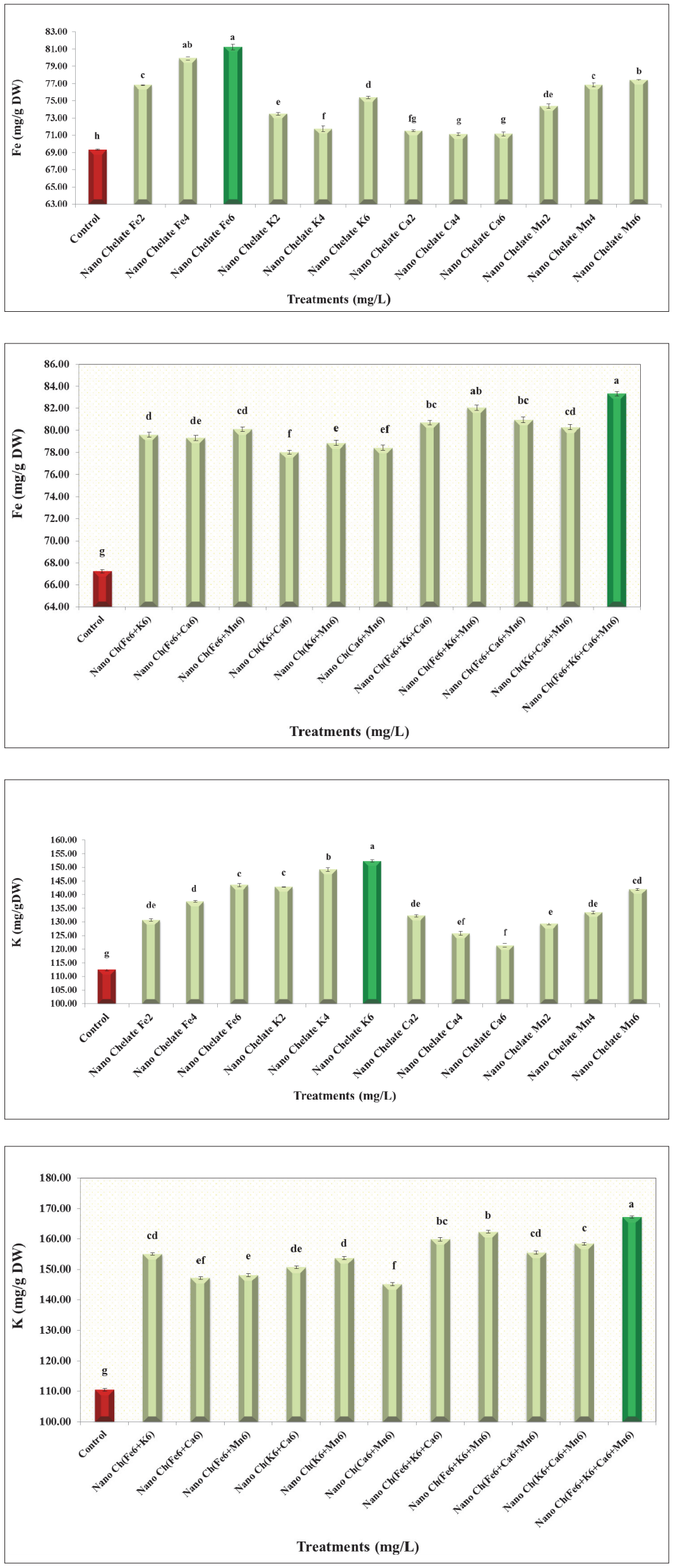

FIGURE 13. Effect of different treatments on the leaf iron content in the first experiment. Vertical bars indicate standard error. Means followed by the same letter are not different according to Duncan's test.

FIGURE 14. Effect of different treatments on the leaf iron content in the second experiment. Vertical bars indicate standard error. Means followed by the same letter are not different according to Duncan's test.

FIGURE 15. Effect of different treatments on leaf potassium content in the first experiment. Vertical bars indicate standard error. Means followed by the same letter are not different according to Duncan's test.

FIGURE 16. Effect of different treatments on leaf potassium content in the second experiment. Vertical bars indicate standard error. Means followed by the same letter are not different according to Duncan's test. 
the effect of treatment on protein content was significant at $5 \%$ treatment level. In the bilateral treatments, $6 \mathrm{mg} \mathrm{L}^{-1}$ Nano K-chelate $+6 \mathrm{mg} \mathrm{L}^{-1} \mathrm{Nano} \mathrm{Ca}$-chelate and in the trilateral treatments, $6 \mathrm{mg} \mathrm{L}^{-1} \mathrm{Nano}$ Fe-chelate $+6 \mathrm{mg} \mathrm{L}^{-1} \mathrm{Nano}$ Ca-chelate $+6 \mathrm{mg} \mathrm{L}^{-1}$ Nano K-chelate had the highest protein content. $6 \mathrm{mg} \mathrm{L}^{-1} \mathrm{Nano}$ Fe-chelate $+6 \mathrm{mg} \mathrm{L}^{-1} \mathrm{Nano} \mathrm{K}$-chelate $+6 \mathrm{mg} \mathrm{L}^{-1}$ Nano Ca-chelate $+6 \mathrm{mg} \mathrm{L}^{-1} \mathrm{Nano} \mathrm{Mn}$-chelate treatment had the highest protein content $\left(70.27 \mu \mathrm{g} \mathrm{mg}^{-1}\right)$ and the control treatment had the lowest protein content $(57.54$ $\mu \mathrm{g} \mathrm{mg}^{-1}$ ) (Figure 8).

\section{Peroxidase enzyme activity}

As shown in Figure 9, the effects of treatments on peroxidase enzyme activity in Mentha piperita, peroxidase enzyme activity was proportionally increased the applied concentrations of iron and calcium nano-chelate. Increasing the concentration of potassium and manganese nano-chelate from 4 to $6 \mathrm{mg} \mathrm{L}^{-1}$ resulted in a greater increase in peroxidase activity than concentration from 2 to $4 \mathrm{mg} \mathrm{L}^{-1} .6 \mathrm{mg} \mathrm{L}^{-1} \mathrm{Nano}$ Fe-chelate treatment with 16.32 Unit enzyme g $^{-1}$ F.W. had the highest and the control treatment with 11.83 Unit enzyme $\mathrm{g}^{-1}$ F.W. had the lowest peroxidase activity.

According to the second experiment (Table 2) associated with the activity of peroxidase enzyme in Mentha piperita in different treatments, the effect of treatment on peroxidase activity was significant at $1 \%$ level at different treatment concentrations. In the bilateral treatments, $6 \mathrm{mg} \mathrm{L}^{-1} \mathrm{Nano}$ Fe-chelate $+6 \mathrm{mg} \mathrm{L}^{-1}$ Nano Ca-chelate and in the trilateral treatments, $6 \mathrm{mg} \mathrm{L}^{-1} \mathrm{Nano}$ Fe-chelate $+6 \mathrm{mg} \mathrm{L}^{-1}$ Nano K-chelate $+6 \mathrm{mg} \mathrm{L}^{-1}$ Nano Ca-chelate had the highest enzyme activity. $6 \mathrm{mg} \mathrm{L}^{-1} \mathrm{Nano}$ Fe-chelate $+6 \mathrm{mg} \mathrm{L}^{-1} \mathrm{Nano} \mathrm{K}$-chelate + $6 \mathrm{mg} \mathrm{L}^{-1} \mathrm{Nano}$ Ca-chelate $+6 \mathrm{mg} \mathrm{L}^{-1}$ Nano Mn-chelate treatment had the highest peroxidase activity with 19.63 Unit enzyme ${ }^{-1}$ F.W. and the control treatment with 21.13 Unit enzyme $\mathrm{g}^{-1}$ F.W. (Figure 10).

\section{Total phenol content of leaves}

As shown in Figure 11, the effects of treatments on the phenol content of Mentha piperita, the phenol content increased significantly among the applied concentrations of Fe nano-chelates. Increasing the concentration of potassium and manganese nano-chelate from 2 to $4 \mathrm{mg} \mathrm{L}^{-1}$ resulted in a greater increase in the amount of phenol than 4 to $6 \mathrm{mg} \mathrm{L}^{-1}$. No significant increase in the phenol content was observed with increasing $\mathrm{CaCl}_{2}$ concentration from 2 to $4 \mathrm{mg} \mathrm{L}^{-1}$. However, the difference was significant with increasing concentration from 4 to $6 \mathrm{mg} \mathrm{L}^{-1} .6 \mathrm{mg} \mathrm{L}^{-1}$ Nano Mn-chelate treatment with $11.69 \mathrm{mg} \mathrm{g}^{-1}$ fresh weight had the highest and control treatment with $8.29 \mathrm{mg} \mathrm{g}^{-1}$ fresh weight had the lowest phenol content.

As shown in Table 2, regarding the phenol content of Mentha piperita in different treatments, the effect of treatment on phenol content at different treatment concentrations was significant at $1 \%$ level. In the bilateral treatments, $6 \mathrm{mg} \mathrm{L}^{-1}$ Nano K-chelate $+6 \mathrm{mg} \mathrm{L}^{-1}$ Nano Mn-chelate and in the trilateral treatments, $6 \mathrm{mg} \mathrm{L}^{-1} \mathrm{Nano}$ Fe-chelate $+6 \mathrm{mg} \mathrm{L}^{-1} \mathrm{Nano}$ $\mathrm{K}$-chelate $+6 \mathrm{mg} \mathrm{L}^{-1} \mathrm{Nano} \mathrm{Mn}$-chelate had the highest phenol content. $6 \mathrm{mg} \mathrm{L}^{-1} \mathrm{Nano}$ Fe-chelate $+6 \mathrm{mg} \mathrm{L}^{-1} \mathrm{Nano}$ K-chelate $+6 \mathrm{mg} \mathrm{L}^{-1}$ Nano Ca-chelate $+6 \mathrm{mg} \mathrm{L}^{-1} \mathrm{Nano}$ Mn-chelate treatment had the highest phenol content with $14.76 \mathrm{mg} \mathrm{g}^{-1}$ fresh weight (Figure 12).

\section{Leaf iron content}

As observed in Figure 13, the effects of treatments on leaf iron content in Mentha piperita, no significant increase in leaf iron content was observed with increasing iron nano-chelate concentration from 4 to $6 \mathrm{mg} \mathrm{L}^{-1}$, but the difference was significant with increasing concentration from 2 to $4 \mathrm{mg} \mathrm{L}^{-1}$. Among different treatments, Nano K-chelate also decreased from $6 \mathrm{mg} \mathrm{L}^{-1}$ Nano K-chelate to $2 \mathrm{mg} \mathrm{L}^{-1}$ Nano K-chelate and $4 \mathrm{mg} \mathrm{L}^{-1} \mathrm{Nano} \mathrm{K}$-chelate, respectively. In addition, at different concentrations of calcium nano-chelate, the leaf iron content decreased from 2 to $6 \mathrm{mg} \mathrm{L}^{-1}$, respectively, but no significant differences were observed between treatments. Significant increase in leaf iron content was observed among the applied concentrations of Mn. $6 \mathrm{mg} \mathrm{L}^{-1}$ Nano Fe-chelate treatment with $81.24 \mathrm{mg} \mathrm{g}^{-1}$ dry weight had the highest and the control treatment with $69.32 \mathrm{mg} \mathrm{g}^{-1}$ dry weight had the lowest leaf iron content.

As shown in the analysis of variance table in the second experiment (Table 2) related to the leaf iron content in Mentha piperita in different treatments, it is found that the effect of treatment on the leaf iron content at different treatments concentrations was significant at $5 \%$ level. In bilateral treatments, $6 \mathrm{mg} \mathrm{L}^{-1}$ Nano Fe-chelate $+6 \mathrm{mg} \mathrm{L}^{-1} \mathrm{Nano}$ Mn-chelate treatment and in trilateral treatments. $6 \mathrm{mg} \mathrm{L}^{-1}$ Nano Fe-chelate $+6 \mathrm{mg} \mathrm{L}^{-1} \mathrm{Nano} \mathrm{Mn}$-chelate $+6 \mathrm{mg} \mathrm{L}^{-1}$ Nano Ca-chelate treatment had the highest leaf iron content. Nano $6 \mathrm{mg} \mathrm{L}^{-1}$ Nano Fe-chelate $+6 \mathrm{mg} \mathrm{L}^{-1} \mathrm{Nano}$ K-chelate $+6 \mathrm{mg} \mathrm{L}^{-1}$ Nano Ca-chelate $+6 \mathrm{mg} \mathrm{L}^{-1}$ Nano Mn-chelate treatment with 83.33 $\mathrm{mg} \mathrm{g}^{-1}$ dry weight had the highest and the control treatment with $67.25 \mathrm{mg} \mathrm{g}^{-1}$ dry weight had the lowest leaf iron content (Figure 14).

\section{Leaf potassium content}

According to Figure 15, of the effects of treatments on leaf potassium content in Mentha piperita, among the applied concentrations of Nano Fe-chelate, leaf potassium content increased from 2 to $6 \mathrm{mg} \mathrm{L}^{-1}$, respectively, but this increase in concentration from 2 to $4 \mathrm{mg} \mathrm{L}^{-1}$ was not significant. There was a significant increase in the leaf potassium content at different concentrations of Nano K-chelate. Leaf potassium content was decreased from 2 to $6 \mathrm{mg} \mathrm{L}^{-1}$ in different concentrations of Nano Ca-chelate, but no significant differences were observed between others. Leaf potassium content also decreased at different concentrations of $\mathrm{Mn}$ from 6 to $2 \mathrm{mg} \mathrm{L}^{-1}$, but no significant differences were seen between the treatments. $6 \mathrm{mg} \mathrm{L}^{-1} \mathrm{Nano}$ Ca-chelate treatment with $153.34 \mathrm{mg} \mathrm{g}^{-1}$ dry weight had the highest and the control treatment with $121.38 \mathrm{mg} \mathrm{g}^{-1}$ dry weight had the lowest potassium content.

As Table 2 in the second experiment regarding leaf potassium content in Mentha piperita in different treatments, the effect of treatment on leaf potassium content at different treatment concentrations was significant at $1 \%$ level. In bilateral treatments, $6 \mathrm{mg} \mathrm{L}^{-1} \mathrm{Nano}$ Fe-chelate $+6 \mathrm{mg} \mathrm{L}^{-1} \mathrm{Nano}$ $\mathrm{K}$-chelate and in trilateral treatments, $6 \mathrm{mg} \mathrm{L}^{-1} \mathrm{Nano}$ Fe-chelate $+6 \mathrm{mg} \mathrm{L}^{-1} \mathrm{Nano} \mathrm{K}$-chelate $+6 \mathrm{mg} \mathrm{L}^{-1} \mathrm{Nano} \mathrm{Mn}$-chelate had the highest leaf potassium content. $6 \mathrm{mg} \mathrm{L}^{-1} \mathrm{Nano}$ Fe-chelate $+6 \mathrm{mg} \mathrm{L}^{-1}$ Nano K-chelate $+6 \mathrm{mg} \mathrm{L}^{-1}$ Nano Ca-chelate $+6 \mathrm{mg} \mathrm{L}^{-1}$ Nano Mn-chelate treatment had the highest leaf potassium content with $167.19 \mathrm{mg} \mathrm{g}^{-1}$ dry weight and control treatment with $110.46 \mathrm{mg} \mathrm{g}^{-1}$ dry weight (Figure 16).

\section{Leaf calcium content}

As indicated in Figure 17 of the effects of treatments on leaf calcium content in Mentha piperita, among the applied concentrations of Nano Fe-chelate, leaf calcium content increased from 2 to $6 \mathrm{mg} \mathrm{L}^{-1}$, respectively. Calcium content was decreased from 2 to $6 \mathrm{mg} \mathrm{L}^{-1}$ at different concentrations of 

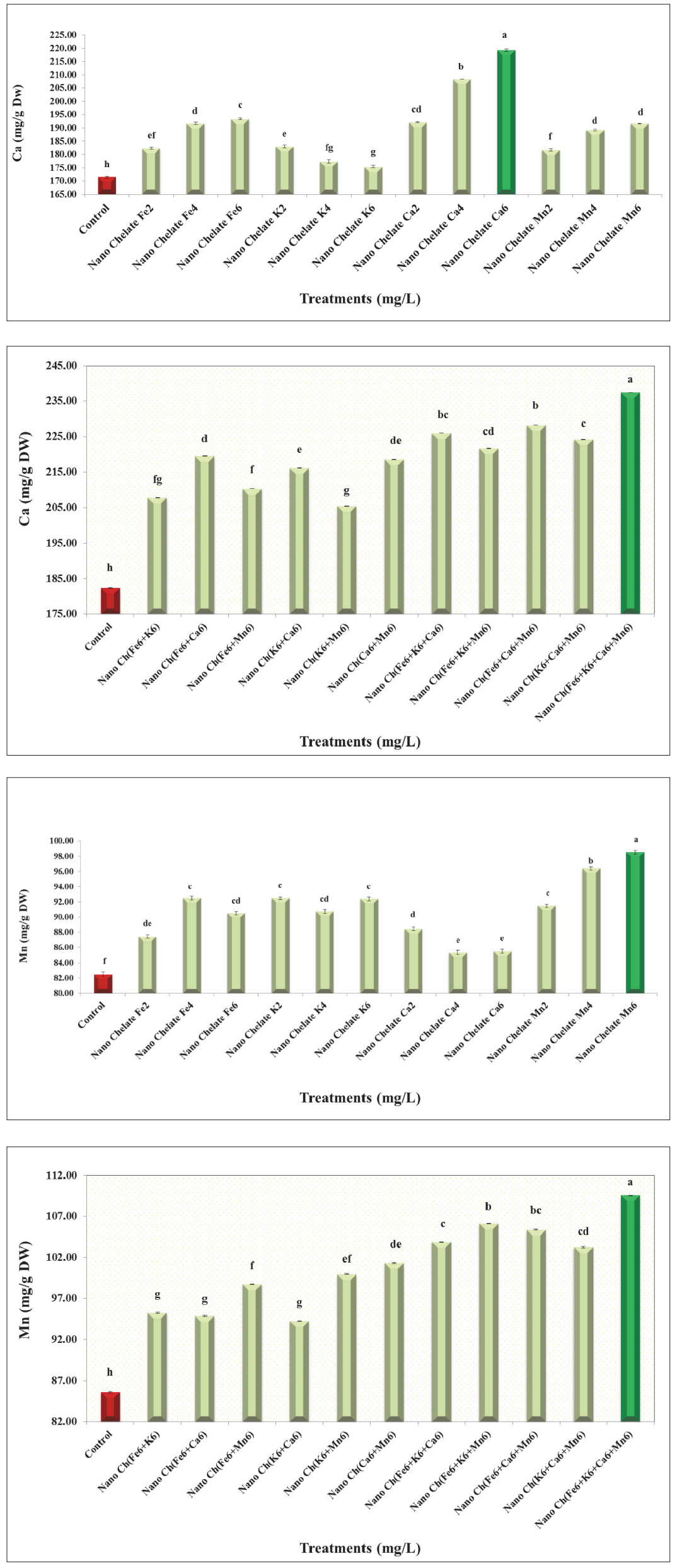

FIGURE 17. Effect of different treatments on the leaf calcium content in the first experiment. Vertical bars indicate standard error. Means followed by the same letter are not different according to Duncan's test.

FIGURE 18. Effect of different treatments on leaf calcium content in the second experiment. Vertical bars indicate standard error. Means followed by the same letter are not different according to Duncan's test.

FIGURE 19. Effect of different treatments on leaf manganese content in the first experiment. Vertical bars indicate standard error. Means followed by the same letter are not different according to Duncan's test.

FIGURE 20. Effect of different treatments on leaf manganese content in the second experiment. Vertical bars indicate standard error. Means followed by the same letter are not different according to Duncan's test. 

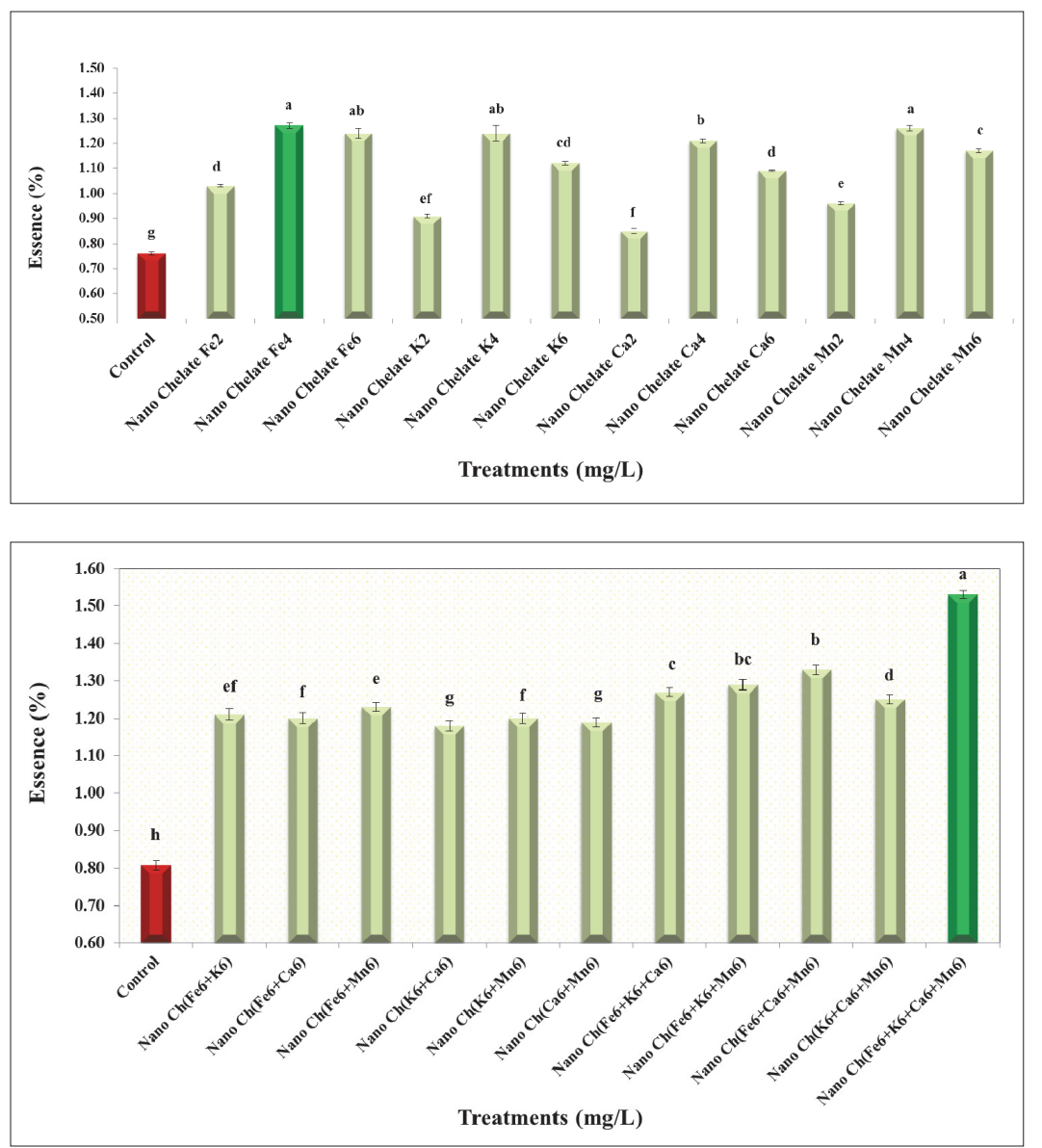

FIGURE 21. Effect of different treatments on essential oil percentage in the first experiment. Vertical bars indicate standard error. Means followed by the same letter are not different according to Duncan's test.

FIGURE 22. Effect of different treatments on essential oil percentage in the second experiment. Vertical bars indicate standard error. Means followed by the same letter are not different according to Duncan's test.
Nano K-chelate, but no significant difference was observed between 4 and $6 \mathrm{mg} \mathrm{L}^{-1}$ treatments. Also, leaf calcium content was significantly increased at different concentrations of Nano Ca-chelate from 2 to $6 \mathrm{mg} \mathrm{L}^{-1}$. Increased leaf calcium content from 2 to $6 \mathrm{mg} \mathrm{L}^{-1}$ was also observed at different concentrations of Nano Mn-chelate, but this increase in concentration from 4 to $6 \mathrm{mg} \mathrm{L}^{-1}$ was not significant. $6 \mathrm{mg} \mathrm{L}^{-1} \mathrm{Nano}$ Ca-chelate treatment with $192.23 \mathrm{mg} \mathrm{g}^{-1}$ dry weight had the highest and the control treatment with $171.48 \mathrm{mg} \mathrm{g}^{-1}$ dry weight had the lowest leaf calcium content.

According to the analysis of variance table in the second experiment (Table 2) associated to the leaf calcium content in Mentha piperita in different treatments, the effect of treatment on leaf calcium content was significant at $5 \%$ level at different treatment concentration. In bilateral treatments, $6 \mathrm{mg} \mathrm{L}^{-1}$ Nano Fe-chelate $+6 \mathrm{mg} \mathrm{L}^{-1}$ Nano Ca-chelate treatment and in trilateral treatments $6 \mathrm{mg} \mathrm{L}^{-1} \mathrm{Nano}$ Fe-chelate $+6 \mathrm{mg} \mathrm{L}^{-1}$ Nano Ca-chelate $+6 \mathrm{mg} \mathrm{L}^{-1}$ Nano Mn-chelate had the highest leaf calcium. $6 \mathrm{mg} \mathrm{L}^{-1} \mathrm{Nano}$ Fe-chelate $+6 \mathrm{mg} \mathrm{L}^{-1}$ Nano K-chelate $+6 \mathrm{mg} \mathrm{L}^{-1} \mathrm{Nano}$ Ca-chelate $+6 \mathrm{mg} \mathrm{L}^{-1} \mathrm{Nano}$ Mn-chelate treatment had the highest leaf calcium content (232.38 $\mathrm{mg} \mathrm{g}^{-1}$ dry weight) and the control treatment with $182.35 \mathrm{mg} \mathrm{g}^{-1}$ dry weight had the lowest leaf calcium content (Figure 18).

\section{Leaf manganese content}

As shown in Figure 19 of the effect of treatments on leaf manganese content in Mentha piperita, among the different concentrations of Nano Fe-chelate, it decreased from Nano $\mathrm{ChFe}_{4}$ ppm to $6 \mathrm{mg} \mathrm{L}^{-1} \mathrm{Nano}$ Fe-chelate and $2 \mathrm{mg} \mathrm{L}^{-1} \mathrm{Nano}$ Fe-chelate, respectively. Among the applied concentrations of potassium nano-chelate, leaf manganese content decreased from $2 \mathrm{mg} \mathrm{L}^{-1} \mathrm{Nano} \mathrm{K}$-chelate to $6 \mathrm{mg} \mathrm{L}^{-1} \mathrm{Nano} \mathrm{K}$-chelate and
$4 \mathrm{mg} \mathrm{L}^{-1}$ Nano K-chelate, respectively. There was no significant difference between treatments. Manganese content was decreased from 2 to 4 and $6 \mathrm{mg} \mathrm{L}^{-1}$ at different concentrations of Nano Ca-chelate, but this decrease was not significant between 4 and $6 \mathrm{mg} \mathrm{L}^{-1}$. There was also a significant increase from 2 to $6 \mathrm{mg} \mathrm{L}^{-1}$ between different concentrations of Nano Mn-chelate. Nano $\mathrm{ChMn}_{6} \mathrm{ppm}$ treatment with $98.52 \mathrm{mg} \mathrm{g}^{-1}$ dry weight had the highest and the control treatment with $82.43 \mathrm{mg} \mathrm{g}^{-1}$ dry weight had the lowest manganese content.

As indicated in the analysis of variance in Table 2 related to leaf manganese content in Mentha piperita in different treatments, the effect of treatment on manganese content was significant at $1 \%$ level at different treatment concentrations. In bilateral treatments, $6 \mathrm{mg} \mathrm{L}^{-1} \mathrm{Nano}$ Fe-chelate + $6 \mathrm{mg} \mathrm{L}^{-1}$ Nano Mn-chelate treatments and in trilateral treatments $6 \mathrm{mg} \mathrm{L}^{-1} \mathrm{Nano}$ Fe-chelate $+6 \mathrm{mg} \mathrm{L}^{-1}$ Nano K-chelate $+6 \mathrm{mg} \mathrm{L}^{-1}$ Nano Mn-chelate treatments had the highest leaf manganese content. $6 \mathrm{mg} \mathrm{L}^{-1} \mathrm{Nano}$ Fe-chelate $+6 \mathrm{mg} \mathrm{L}^{-1}$ Nano K-chelate $+6 \mathrm{mg} \mathrm{L}^{-1} \mathrm{Nano}$ Ca-chelate $+6 \mathrm{mg} \mathrm{L}^{-1} \mathrm{Nano} \mathrm{Mn}$-chelate treatment with $109.56 \mathrm{mg} \mathrm{g}^{-1}$ dry weight had the highest manganese content and the control treatment with 85.61 $\mathrm{mg} \mathrm{g}^{-1}$ dry weight had the lowest leaf manganese content (Figure 20).

\section{Essential oil percentage}

According to Figure 21, the effects of treatments on the essential oil percentage of Mentha piperita, among different concentrations of Nano Fe-chelate, it decreased from $4 \mathrm{mg} \mathrm{L}^{-1}$ Nano Fe-chelate to $6 \mathrm{mg} \mathrm{L}^{-1} \mathrm{Nano}$ Fe-chelate and $2 \mathrm{mg} \mathrm{L}^{-1}$ Nano Fe-chelate, respectively, but there was no significant difference between treatments. Among the applied concentrations of potassium nano-chelate, the essential oil percentage decreased significantly from $4 \mathrm{mg} \mathrm{L}^{-1} \mathrm{Nano}$ K-chelate to 
$6 \mathrm{mg} \mathrm{L}^{-1}$ Nano K-chelate and $2 \mathrm{mg} \mathrm{L}{ }^{-1}$ Nano K-chelate, respectively. In addition, the essential oil percentage in the applied concentrations of Nano Ca-chelate decreased significantly from $4 \mathrm{mg} \mathrm{L}^{-1}$ Nano Ca-chelate to $6 \mathrm{mg} \mathrm{L}^{-1}$ Nano Ca-chelate and $2 \mathrm{mg} \mathrm{L}^{-1}$ Nano Ca-chelate, respectively. There was also a significant decrease in the percentage of essential oil in the applied concentrations of $\mathrm{MnCl}_{2}$ from $4 \mathrm{mg} \mathrm{L}^{-1}$ Nano $\mathrm{Mn}$-chelate to $6 \mathrm{mg} \mathrm{L}^{-1} \mathrm{Nano} \mathrm{Mn}$-chelate and $2 \mathrm{mg} \mathrm{L}^{-1}$ Nano Mn-chelate, respectively. $\mathrm{Nano} \mathrm{ChFe}_{4}$ ppm treatment with $1.27 \%$ had the highest and the control treatment with $0.76 \%$ had the lowest essential oil percentage.

As shown in the analysis of variance table in the second experiment (Table 2) related to the essential oil percentage of Mentha piperita in different treatments, the effect of treatment on essential oil percentage at different concentrations was significant at $1 \%$ level. In bilateral treatments, $6 \mathrm{mg} \mathrm{L}^{-1}$ Nano Fe-chelate $+2 \mathrm{mg} \mathrm{L}^{-1}$ Nano Mn-chelate and trilateral treatments $6 \mathrm{mg} \mathrm{L}^{-1} \mathrm{Nano}$ Fe-chelate $+6 \mathrm{mg} \mathrm{L}^{-1} \mathrm{Nano}$ Ca-chelate $+6 \mathrm{mg} \mathrm{L}^{-1} \mathrm{Nano} \mathrm{Mn}$-chelate had the highest percentage of essential oil. $6 \mathrm{mg} \mathrm{L}^{-1} \mathrm{Nano}$ Fe-chelate $+6 \mathrm{mg} \mathrm{L}^{-1} \mathrm{Nano}$ K-chelate $+6 \mathrm{mg} \mathrm{L}^{-1} \mathrm{Nano}$ Ca-chelate $+6 \mathrm{mg} \mathrm{L}^{-1}$ Nano Mn-chelate treatment with $1.53 \%$ had the highest and the control treatment with $0.81 \%$ had the lowest essential oil percentage (Figure 22).

\section{Discussion}

Among the nutrients, 17 elements, including high-consumption elements such as potassium and calcium and low-consumption elements such as iron and manganese, are essential for plant growth (Liu, 2009). Iron plays a role in oxidation and reductive processes and causes electron transfer by altering the capacity, which is a very important role in plant metabolism. Iron is essential for protein synthesis and since iron plays a key role in the synthesis of proteins associated with chlorophyll, its deficiency causes chlorophyll degradation, which is why yellow color due to iron deficiency occurs. Of course, except for the veins, the entire leaf surface is yellow in color, first appearing in the young leaves and the upper part of the stem, and gradually encompasses the whole plant. Calcium is also one of the important nutrients for root development and its tasks; in other words, the optimal supply of calcium stimulates the growth of capillary roots and the development of the root system, enhancing growth, increasing photosynthesis and plant yield. It also increases cell wall strength and plant tolerance against cellular damage caused by pathogens. Calcium pectate is one of the constituents of the middle layers of the cell wall. It is involved in the binding of polysaccharides and cell wall-forming proteins, which is a cofactor of amylase and ATP-ase enzymes, and is effective in the stability and mechanical strength of the cell wall (Mehran et al., 2008). Potassium is also of particular importance in young root tip leaves and meristematic tissues, and it is involved in almost all plant metabolism processes such as photosynthesis, carbohydrate production, nitrate recovery, amino acid synthesis, and protein synthesis. It acts as an activator of a number of plant enzymes and plays an important role in regulating the respiration and water status of plant cells. Potassium is also important in opening and closing stomatal cells and promotes root growth. Manganese is also one of the low-consumption elements but indispensable for plant growth and development, which has many roles in plants. It is essential for chlorophyll production and it is involved in enzymatic processes, nitrate reduction, protein metabolism and neutralization of free radicals. Manganese is the activator of the effective enzymes in the production of fatty acids and is essential for carbohydrate and nitrogen metabolism. Manganese deficiency, like other micronutrients, is more common in soils with alkaline $\mathrm{pH}$ and manganese deficiency symptoms appear as mesophilic yellowing and pale green spots on the leaf surface. In this study, the elements were first sprayed with foliar application on soluble plants separately; the results indicated that in most of the traits evaluated, the highest level of applied element improved its trait. Then the effects of bilateral, trilateral and all elements application on the studied traits were investigated. The results showed that the application of two or three elements simultaneously had greater improvement in the desired traits than the application of elements individually. Any kind of herbal drugs is influenced by many factors. Genetic, pre-harvest (season of harvest, soil, type of water) and post-harvest factors (storage, temperature, moisture) can affect total phenolic, flavonoid, and antioxidant capacity as well as other elements and compounds. However, the best result in improving the traits was the simultaneous application of all four elements as foliar application. In general, iron, calcium, potassium and manganese have been involved in many physiological processes such as photosynthesis, enzyme activity, growth hormone production, water uptake, oxidation and reduction process, chlorophyll formation, and so on. Their deficiency can lead to an imbalance of nutrients in the plant and ultimately reduce the quantity and quality of the product. Foliar application of these elements can be used in early vegetative growth conditions when crop soil is deficient or low in nutrients. This issue increases growth, yield and essential oil percentage, which confirms the results of two experiments in this study.

\section{References}

Ahmadi, A., and Jabbari, F. (2009). Introduction to Plant Physiology (Tehran: Tehran University Press), p. 163-158.

Arnon, D.I. (1949). Copper enzymes in isolated chloroplasts. Polyphenoloxidase in Beta vulgaris. Plant Physiol. 24,1-15. https:// doi.org/10.1104/pp.24.1.1.

Bradford, M.M. (1976). A rapid and sensitive method for the quantization of microgram quantities of protein utilizing the principle of protein dye binding. Anal. Biochem. 72, 248-254. https://doi.org/10.1016/0003-2697(76)90527-3.

Cui, H., Sun, C., Liu, Q.,. Jiang, J., and Gu, W. (2006). Applications of Nanotechnology in Agro-chemical Formulation, Perspectives, Challenges and Strategies (Beijing, China: Institute of Environment and Sustainable Development in Agriculture, Chinese Academy of Agricultural Sciences), p. 1-6.

Ezhilmathi, K., Singh, V., Arora, P., and Sairam, R.K. (2007). Effect of 5-sulfocalicylic acid on antioxidant in relation to vase life of gladiolus cut flower. Plant Growth Regul. 51, 99-108. https://doi. org/10.1007/s10725-006-9142-2.

Florence, V.D., Daniel, E., and Badr, A. (2002). Effect of copper on growth and photosynthesis of mature and expanding leaves in cucumber plants. Plant Sci. 163, 53-58. https://doi.org/10.1016/ S0168-9452(02)00060-2.

Janaki, P.J., Adhikari, R.S., and Negi, J.S. (2016). Effect of nitrogen, phosphorus and potassium on growth and green herb yield of Thymus serphyllum. Int. J. Curr. Microbiol. Appl. Sci. 5, 406-410. https://doi.org/10.20546/ijcmas.2016.501.040.

Liu, X., Feng, S., Zhang, J., Zhang, Q., Xiao, Z., and Wang, Y. (2009). Preparation and testing of cementing nano-subnano composites of slower controlled release of fertilizers. Sci. Agric. Sinica 39, 15981604. 
Malik, C.P., and Singh, M.B. (1980). Plant Enzymology and Histoenzymology (New Delhi: Kalyani Publishers), 286 pp.

Mehrafarin, A., Naghdi Badi, H., Mirzai Motlagh, M., Salehi, M., and Ghiasi Yekta, M. (2017). Phytochemical and morphophysiological responses of Dill (Anethum graveolens L.) to foliar application of potassium sulfate and methanol biostimulant. J. Med. Plants 4, 93109.

Mehran, A, Hossein, D.G., and Tehranifar, A. (2008). Effects of preharvest calcium fertilization on vase life of rose cut flowers cv. Alexander. Acta Hortic. 804, 215-218. https://doi.org/10.17660/ ActaHortic.2008.804.28.

Mengel, K., and Kirkby, E.A. (1973). Principles of Plant Nutrition, $5^{\text {th }}$ edn. (Dordrecht, The Netherlands: Kluwer Academic Publishers).

Rita, P., and Animesh, D.K. (2011). An updated overview on peppermint (Mentha piperita L.). Int. Res. J. Pharm. 2, 1-10.

Shaviv, A. (2005). Controlled release of fertilizers. IFA International Workshop on Enhanced-Efficiency Fertilizers, 28-30 June, Frankfurt, Germany.

Yadegari, M. (2017). Effects of Zn, Fe, Mn and Cu foliar application on essential oils and morpho-physiological traits of Lemon Balm (Melissa officinalis L.). J. Essent. Oil Bear. Plants 20, 485-495. https:// doi.org/10.1080/0972060X.2017.1325010.

Received: Jun. 17, 2020

Accepted: Sep. 23, 2020

Addresses of authors:

Hamidreza Bagheri ${ }^{1}$, Alireza Ladan Moghadam ${ }^{2, *}$,

Elham Danaee ${ }^{2}$ and Vahid Abdossi ${ }^{3}$

${ }^{1}$ Department of Horticultural Sciences, Aliabad Katoul

Branch, Islamic Azad University, Gorgan, Iran

2 Department of Horticulture, Garmsar Branch, Islamic Azad

University, Garmsar, Iran.

${ }^{3}$ Department of Horticultural Sciences, Science and

Research Branch, Islamic Azad University, Tehran, Iran

* Corresponding author;

E-mail: Moghadam.alireza@gmail.com 